\title{
Front Matter: Volume 10430
}

, "Front Matter: Volume 10430," Proc. SPIE 10430, High-Performance Computing in Geoscience and Remote Sensing VII, 1043001 (7 November 2017); doi: $10.1117 / 12.2304036$

SPIE. Event: SPIE Remote Sensing, 2017, Warsaw, Poland 


\title{
High-Performance Computing in Geoscience and Remote Sensing VII
}

\author{
Bormin Huang \\ Sebastián López \\ Zhensen Wu \\ Jose M. Nascimento \\ Jun Li \\ Valeriy V. Strotov \\ Editors
}

\section{2-13 September 2017 \\ Warsaw, Poland}

Sponsored and Published by

SPIE

Cooperating Organisations

Innovation Centre for Sensor and Imaging Systems (United Kingdom)

ADS Scotland (United Kingdom)

The Knowledge Transfer Network (United Kingdom)

Visit Scotland (United Kingdom)

European Regional Development Fund (Belgium)

Technology Scotland (United Kingdom)

European Association of Remote Sensing Companies (Belgium)

European Association of Remote Sensing Laboratories (Germany)

The British Association of Remote Sensing Companies (United Kingdom)

Remote Sensing \& Photogrammetry Society (United Kingdom) 
The papers in this volume were part of the technical conference cited on the cover and title page. Papers were selected and subject to review by the editors and conference program committee. Some conference presentations may not be available for publication. Additional papers and presentation recordings may be available online in the SPIE Digital Library at SPIEDigitallibrary.org.

The papers reflect the work and thoughts of the authors and are published herein as submitted. The publisher is not responsible for the validity of the information or for any outcomes resulting from reliance thereon.

Please use the following format to cite material from these proceedings:

Author(s), "Title of Paper," in High-Performance Computing in Geoscience and Remote Sensing VII, edited by Bormin Huang, Sebastián López, Zhensen Wu, Jose M. Nascimento, Jun Li, Valeriy V. Strotov, Proceedings of SPIE Vol. 10430 (SPIE, Bellingham, WA, 2017) Seven-digit Article CID Number.

ISSN: 0277-786X

ISSN: 1996-756X (electronic)

ISBN: 9781510613249

ISBN: 9781510613256 (electronic)

Published by

SPIE

P.O. Box 10, Bellingham, Washington 982270010 USA

Telephone +1 3606763290 (Pacific Time) · Fax +1 3606471445

SPIE.org

Copyright @ 2017, Society of Photo-Optical Instrumentation Engineers.

Copying of material in this book for internal or personal use, or for the internal or personal use of specific clients, beyond the fair use provisions granted by the U.S. Copyright Law is authorized by SPIE subject to payment of copying fees. The Transactional Reporting Service base fee for this volume is $\$ 18.00$ per article (or portion thereof), which should be paid directly to the Copyright Clearance Center (CCC), 222 Rosewood Drive, Danvers, MA 01923. Payment may also be made electronically through CCC Online at copyright.com. Other copying for republication, resale, advertising or promotion, or any form of systematic or multiple reproduction of any material in this book is prohibited except with permission in writing from the publisher. The CCC fee code is 0277 $786 \mathrm{X} / 17 / \$ 18.00$.

Printed in the United States of America.

Publication of record for individual papers is online in the SPIE Digital Library.

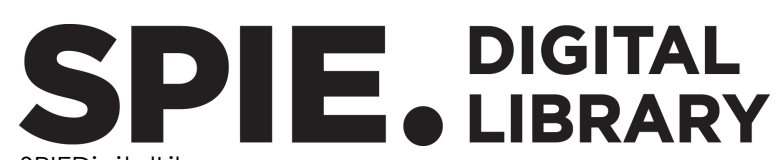

SPIEDigitallibrary.org

Paper Numbering: Proceedings of SPIE follow an e-First publication model. A unique citation identifier (CID) number is assigned to each article at the time of publication. Utilization of CIDs allows articles to be fully citable as soon as they are published online, and connects the same identifier to all online and print versions of the publication. SPIE uses a seven-digit CID article numbering system structured as follows:

- The first five digits correspond to the SPIE volume number.

- The last two digits indicate publication order within the volume using a Base 36 numbering system employing both numerals and letters. These two-number sets start with $00,01,02,03,04$, $05,06,07,08,09,0 A, 0 B \ldots$... Z, followed by 10-1Z, 20-2Z, etc. The CID Number appears on each page of the manuscript. 


\title{
Contents
}

\author{
$\checkmark$ Authors \\ vii Conference Committee
}

SESSION 1 HIGH PERFORMANCE COMPUTING I

1043002 On the use of Jetson TX1 board for parallel hyperspectral compressive sensing [10430-1]

1043003 Low-complexity multiple collaborative representations for hyperspectral image classification [10430-2]

1043004 Real-time implementation of digital stabilization for high-resolution Earth observation imaging [10430-3]

1043005 Deduce atmosphere information with optical observations of aurora spectral images [10430-4]

1043006 The implementation of aerial object recognition algorithm based on contour descriptor in FPGA-based on-board vision system [10430-5]

$1043007 \quad$ Embedded digital oilfield model [10430-25]

\section{SESSION 2 HIGH PERFORMANCE COMPUTING II}

1043009 Spaceborne synthetic aperture radar signal processing using FPGAs [10430-12]

10430 OA Parallel exploitation of a spatial-spectral classification approach for hyperspectral images on RVC-CAL (Best Student Paper Award) [10430-13]

$10430 \mathrm{OB}$ Technology for organization of the onboard system for processing and storage of ERS data for ultrasmall spacecraft [10430-14]

10430 OC Wavelet-based multi-component denoising on GPU to improve the classification of hyperspectral images [10430-15]

10430 OD A FPGA implementation for linearly unmixing a hyperspectral image using OpenCL [10430-16]

\section{POSTER SESSION}

10430 OG GPU implementation of discrete particle swarm optimization algorithm for endmember extraction from hyperspectral image [10430-11] 
10430 0J Development of Geometry Normalized Electromagnetic System (GNES) instrument for metal defect detection [10430-20]

10430 OK High-performance technology for indexing of high volumes of Earth remote sensing data [10430-21]

10430 OM Remote sensing for aerosol particles in marine atmosphere using scattering of optical vortex [10430-23] 


\section{Authors}

Numbers in the index correspond to the last two digits of the seven-digit citation identifier (CID) article numbering system used in Proceedings of SPIE. The first five digits reflect the volume number. Base 36 numbering is employed for the last two digits and indicates the order of articles within the volume. Numbers start with 00, 01, 02, 03, 04, 05, 06, 07, 08, 09, OA, OB...0Z, followed by 10-1Z, 20-2Z, etc.

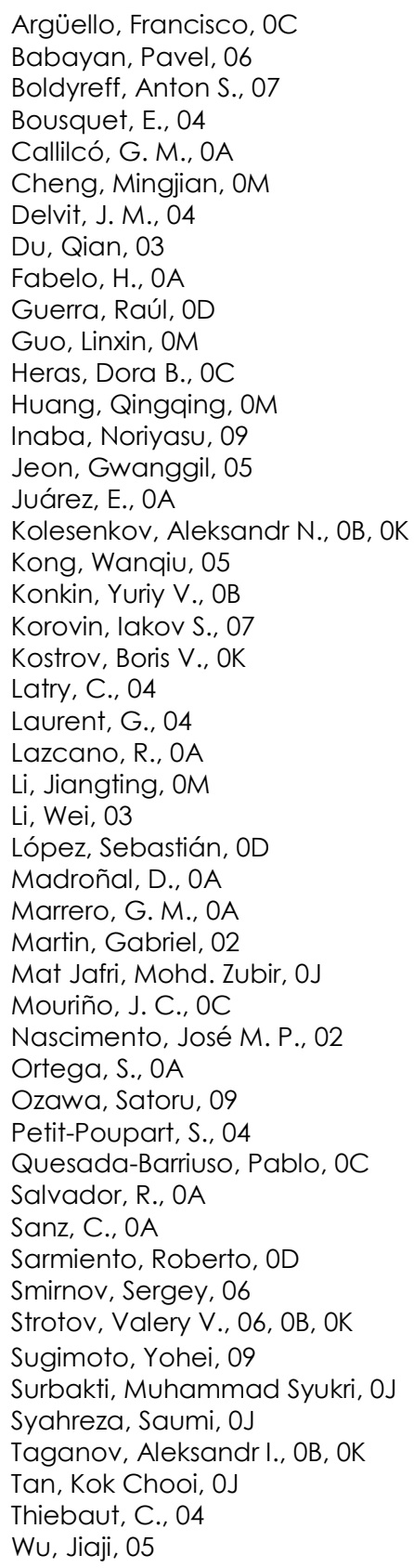

Wu, Tao, 05

Wu, Yuanfeng, $0 G$

$\mathrm{Xu}, \mathrm{Yan}, \mathrm{O3}$

Yan, $X u, O M$

Younan, Nicolas H., 03

YU, Chaoyin, OG

Yuan, Zhengwu, OG

Zakaria, Zakaria, 0J 
Proc. of SPIE Vol. $104301043001-6$

Downloaded From: https://www.spiedigitallibrary.org/conference-proceedings-of-spie on 26 Apr 2023 Terms of Use: https://www.spiedigitallibrary.org/terms-of-use 


\section{Conference Committee}

Symposium Chair

Klaus Schäfer, (Retired) Karlsruhe Institute of Technology, Institute of Meteorology and Climate Research (Germany)

Symposium Co-chair

Christopher M. U. Neale, University of Nebraska-Lincoln

(United States), Daugherty Water for Food Institute (United States)

Conference Chairs

Bormin Huang, University of Wisconsin-Madison (United States)

Sebastián López, Universidad de Las Palmas de Gran Canaria (Spain)

Zhensen Wu, Xidian University (China)

Conference Co-chairs

Jose M. Nascimento, Instituto de Telecomunicações (Portugal)

Jun Li, Sun Yat-Sen University (China)

Valeriy V. Strotov, Ryazan State Radio Engineering University

(Russian Federation)

Conference Programme Committee

Saeed H. Al-Mansoori, Emirates Institution for Advanced Science and Technology (United Arab Emirates)

Boris A. Alpatov, Ryazan State Radio Engineering University (Russian Federation)

Dora Blanco Heras, Universidad de Santiago de Compostela (Spain)

Chein-I Chang, University of Maryland, Baltimore County (United States)

Yang-Lang Chang, National Taipei University of Technology (Taiwan)

Mingmin Chi, Fudan University (China)

Qian Du, Mississippi State University (United States)

Dustin Feld, Universität zu Köln (Germany)

Carlos E. Garcia Gonzalez, Universidad Complutense de Madrid (Spain)

Lixin Guo, Xidian University (China)

Eduardo Juarez, Universidad Politécnica de Madrid (Spain)

Francesco Leporati, Universitá degli Studi di Pavia (Italy)

Qiguang Miao, Xidian University (China)

Caner Özcan, Karabük Üniversitesi (Turkey) 
Shen-En Qian, Canadian Space Agency (Canada)

Enrique S. Quintana-Orti, Universidad Jaume I (Spain)

Jarno Mielikainen, University of Wisconsin-Madison (United States)

Antonio J. Plaza, Universidad de Extremadura (Spain)

Sergio Sanchez Martinez, Masdar Institute of Science \& Technology (United Arab Emirates)

Roberto Sarmiento, Universidad de Las Palmas de Gran Canaria (Spain)

Yuliya Tarabalka, INRIA Sophia Antipolis - Méditerranée (France)

Carole Thiebaut, Centre National d'Études Spatiales (France)

Tanya Vladimirova, University of Surrey (United Kingdom)

Shih-Chieh Wei, Tamkang University (Taiwan)

Jiaji Wu, Xidian University (China)

Yuanfeng Wu, Institute of Remote Sensing and Digital Earth (China)

\section{Session Chairs}

1 High Performance Computing I

Bormin Huang, University of Wisconsin-Madison (United States)

2 High Performance Computing II

José M. P. Nascimento, Instituto de Telecomunicações (Portugal)

Sebastián López, Universidad de Las Palmas de Gran Canaria (Spain) 